\title{
To assess the knowledge attitude and practices regarding women empowerment and its impact on health status of women in rural and urban areas attached with Govt. Medical College, Patiala, Punjab
}

\author{
Singh G. ${ }^{1}$, Mitra Y. ${ }^{2 *}$, Kaur S. ${ }^{3}$, Singh Balgir R. ${ }^{4}$ \\ DOI: https://doi.org/10.17511/ijphr.2019.i2.06
}

${ }^{1}$ Gurmeet Singh, Professor, Government Medical College, Patiala, Punjab, India.

2* Yash Mitra, Assistant Professor, Department of Community Medicine, Punjab Institute of Medical Sciences, Jalandhar, Punjab, India.

3 Sukhwinder Kaur, Nodal Officer O/o DHS, Chandigarh, Punjab, India.

${ }^{4}$ Rajinder Singh Balgir, Professor (Ex), Department of Community Medicine, Government Medical College, Patiala, Punjab, India.

Introduction: Women's empowerment, or autonomy, is a multifaceted concept. In a patriarchal society, as exists in large parts of India, men are placed in a more advantageous position than women. The state of male supremacy is reflected in the child rearing and caring practices, the Access to nutrition, child care and education all favour boys over girls. Material and Methods: In this cross-sectional study, all married females from 200 households were interviewed in rural ( $\mathrm{CHC}$ Bhadson) and urban ( $\mathrm{MCH}$ Center Tripuri) field practice areas attached with department of Community Medicine, Government Medical College, Patiala (100 households each from rural and urban). Results: After interviewing 110 women in rural and 103 in urban area, the data regarding socio demographic profile of the respondents and their knowledge, attitude and practices regarding various domains of empowerment and their health status was compiled and analysed statistically. Knowledge regarding legal age of marriage was higher in urban women (78.64\%) as compared to rural women (43.64\%).Conclusion: From the information it can be concluded that the attitudes or opinions of the women in a family are definitely influenced by the better empowerment status of the women. It is evident that if the empowerment (education, occupation and financial status) of the reproductive age group of women is enhanced it will lead to better health status. Recommendations: It is recommended that provision of education, employment and improving their socio economic status by the Government will lead to modification in the overall health scenario of the family, community, state as well as a country.

Keywords: Empowerment, Economic, Health, Discriminated, Compiled

Corresponding Author

Yash Mitra, Assistant Professor, Department of Community Medicine, Punjab Institute of Medical Sciences, Jalandhar, Punjab, India.

Email: mitrayash@yahoo.com
How to Cite this Article

Singh G, Mitra Y, Kaur S, Balgir RS. To assess the knowledge attitude and practices regarding women empowerment and its impact on health status of women in rural and urban areas attached with Govt. Medical College, Patiala, Punjab. Public Health Rev Int J Public Health Res. 2019;6(2):82-88.

Available From

https://publichealth.medresearch.in/index.php/ijphr/ article/view/104

$\begin{array}{cc}\begin{array}{c}\text { Manuscript Received } \\ \text { 2019-02-02 }\end{array} & \begin{array}{c}\text { Review Round 1 } \\ 2019-02-11\end{array} \\ \text { Conflict of Interest } \\ \text { No } & \text { Funding } \\ \text { Nil }\end{array}$

Review Round 2
2019-02-16
Ethical Approval
Yes

Review Round 3

Accepted 2019-02-21

(c) 2019 by Gurmeet Singh, Yash Mitra, Sukhwinder Kaur, Rajinder Singh Balgir and Published by Siddharth Health Research and Social Welfare Society. This is an Open Access article licensed under a Creative Commons Attribution 4.0 International License https://creativecommons.org/licenses/by/4.0/ unported [CC BY 4.0].

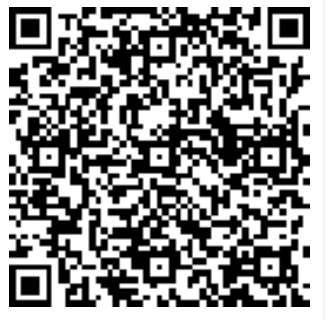




\section{Introduction}

Women's empowerment, or autonomy, is a multifaceted concept. In a patriarchal society, as exists in large parts of India, men are placed in a more advantageous position than women. The family lineage and living arrangements are centered on men, and inheritance and succession practices tend to neglect women as well.

The state of male supremacy is reflected in the child rearing and caring practices, the celebrations for the birth of a male child and the differential treatment meted out to boys. Access to nutrition, child care and education all favour boys over girls. From a very early age, a girl is socialized to give priority to the needs of the male members in the family.

The effect of these practices is a tilt in the power relations in favour of males. Women's empowerment is essentially an effort to rectify this imbalance and attain gender equity [1].

The most common indicators for measuring empowerment measure capabilities, education and health in particular, and control over economic and political resources and decision-making. Numerous factors environmental, socio-cultural, political and economic affect women's health outcomes. The excess health burden for women negatively impacts the health of families and communities [2].

The WHO concludes that there is significant greater impact on several health related outcomes, including mortality rates for children under five years of age, adult female and male mortality, adult female and male life expectancy at birth and total fertility rates when it is compared to income, women's educational level, particularly the aspects of generation and utilization of new knowledge [3].

Gains in women's health have been uneven and gaps continue to exist in accessing healthcare, which reflects class ethnic, and rural and urban inequalities among others. Lack of infrastructure, capacity building and financing continue to be the issues as does societal discrimination. Hence, WHO (2008) report focuses on primary healthcare as a means to address inequalities in access [4 5].

The health of Indian women is intrinsically linked to their status in society. Research on women's status has found that the contributions made by Indian women to families are often overlooked, and instead they are viewed as economic burdens.
Further, Indian women have low levels of both education and formal labour force participation. They typically have little autonomy, living under the control of firstly their fathers, then their husbands, and finally their sons. All of these factors exert a negative impact on the health status of Indian women.

Punjab has emerged as the most developed, but least gender sensitive State of India. On one hand, women are defied, put on a pedestal and worshipped but on the other, they are suppressed and subordinated, denied even the right to take birth. The first Guru of Sikhs Guru Nanak Dev Ji, emphasized the role and importance of women in the family and community.

He stated, "So kyunmandaaakhiejitjamehrajan" which is quoted in Shri Guru Granth Sahib Ji. At the same time, the population culture of Punjab legitimizes numerous practices derogatory to women. Women continue to be worshipped as kanya, devi yet they also continue to be subordinated, suppressed and discriminated against in everyday life.

Thus, it is recognized that empowerment is a multidimensional term. As a result, several efforts have been made to develop comprehensive framework to delineate the various dimensions along which women can be empowered. Also, the studies have shown that empowerment cannot be understood without understanding the socio-cultural as well as the political and economic context in which development takes place.

Then there are studies that show that women's empowerment reflects community norms, rather than women's individual traits. As very few studies have been done in this part of country so present study was planned to know the knowledge, attitude and practices regarding women empowerment and their health status.

\section{Objectives}

To study the knowledge, attitude and practices regarding women empowerment and its impact on the health status of women in rural and urban areas of district Patiala.

\section{Material and Methods}

Setting and Type of Study: The study was carried out in Rural (CHC Bhadson) and Urban $\mathrm{MCH}$ (Center Tripuri). It is cross-sectional study. 
Sampling Method: Interview technique was used to fill the predesigned and pretested proforma.

Sample Collection: All married females from 200 households were interviewed in rural ( $\mathrm{CHC}$ Bhadson) and urban ( $\mathrm{MCH}$ Center Tripuri) field practice areas attached with department of Community Medicine, Government Medical College, Patiala (100 households each from rural and urban). And urban (MCH Center Tripuriatt) field practice area attached with department of community medicine, Government medical college Patiala.

Married females from age group of 18 - 49 years were included in this study. A pre-tested proforma was used to collect information of knowledge, attitude and practices (KAP) regarding women empowerment and their health status. Every 5th house was selected by systematic random sampling technique in both the areas.

In this way, 200 houses including 100 each in urban and rural areas were surveyed and every married women in the house in the age group of $18-49$ years was interviewed. Total 110 married females from rural and 103 married females from urban area were included in the study.

Information was collected regarding their sociodemographic characteristics, their health status, their knowledge, attitude and practices regarding various domains under study. Every women was interviewed individually. On an average each women was interviewed for 45 minutes. The study was conducted between March 2011 to June 2012.

Inclusion Criteria: Those women who were married from age group 18-49 years and submitted written consent to participate in the study included.

Exclusion Criteria: those married females were excluded from the study who were not fulfilling the above criteria and refused to submit the written consent for the study.

Statistical Methods: were used to collect so and analysis the data.

Ethical Consideration and Permission: The permission was obtained from the Institutional Ethical Committee.

\section{Results}

The major findings of the study are as below:

Table-1: Knowledge of Respondents about

Legal age of Marriage
\begin{tabular}{|l|l|l|}
\hline Knowledge about Legal Age & Rural $(\boldsymbol{n}=\mathbf{1 1 0})$ & Urban $(\mathrm{n}=\mathbf{1 0 3})$ \\
\hline Yes & $48(43.64)$ & $81(78.64)$ \\
\hline No & $62(56.36)$ & $22(21.36)$ \\
\hline
\end{tabular}

Table 1 depicts that legal age of marriage is higher in Urban women where $78.64 \%$ women knew about legal age of marriage but in Rural only $43.64 \%$ women knew that legal age of marriage is 18 years notified by the Govt. of India.

The Mean age of marriage in rural and urban areas was 18.89 years and 21.71 years respectively. In both the areas majority were Hindus (53.64\% rural and $77.67 \%$ in urban area respectively).

Table-2: Status of Respondents Regarding Treatment of Anaemia During Pregnancy.

\begin{tabular}{|l|l|l|}
\hline \multicolumn{1}{|c|}{ Treatment of Anaemia } & \multicolumn{1}{|c|}{ Rural $(\mathbf{n = 1 1 0 )}$} & \multicolumn{1}{|c|}{ Urban $(\mathrm{n}=\mathbf{1 0 3})$} \\
\hline Yes & $54(49.09)$ & $66(64.08)$ \\
\hline No & $53(48.18)$ & $32(31.07)$ \\
\hline Never Conceived & $03(2.73)$ & $05(4.85)$ \\
\hline
\end{tabular}

Table 2 shows that $64.08 \%$ urban and $49.09 \%$ rural women received treatment for anaemia during pregnancy. In rural area $48.18 \%$ pregnant women revealed that they were not treated for anaemia.

Table- 3: Status of Causalities Regarding
Respondent's Child
\begin{tabular}{|l|l|l|}
\hline \multicolumn{1}{|c|}{ Status of Causality } & \multicolumn{1}{|c|}{ Rural $(\mathbf{n}=\mathbf{1 1 0})$} & Urban $(\mathbf{n}=\mathbf{1 0 3})$ \\
\hline Yes & $12(10.91)$ & $06(5.83)$ \\
\hline No & $98(89.09)$ & $97(94.17)$ \\
\hline
\end{tabular}

Table 3 reveals that $10.91 \%$ rural and $5.83 \%$ urban women had lost their children due to some illness or accident. In the rural area $75 \%$ of children died were females whereas $66.67 \%$ children died in urban area were males.

Table-4: Working Status of Respondents

\begin{tabular}{|l|l|l|}
\hline \multicolumn{1}{|c|}{ Working Status } & \multicolumn{1}{|c|}{ Rural $(\mathbf{n = 1 1 0})$} & \multicolumn{1}{c|}{ Urban $(\mathbf{n = 1 0 3 )}$} \\
\hline Working & $08(07.27)$ & $21(20.39)$ \\
\hline Not working & $102(92.73)$ & $82(79.61)$ \\
\hline
\end{tabular}

Table 4 reveals that there is slightly higher percentage of women working in urban areas as compared to rural areas.

Table-5: Attitude of Spouse towards Respondents

\begin{tabular}{|l|l|l|l|l|}
\hline \multirow{2}{*}{ Attitude of Spouse } & \multicolumn{2}{|c|}{ Rural $(\mathrm{n}=110)$} & \multicolumn{2}{c|}{ Urban $(\mathrm{n}=103)$} \\
\cline { 2 - 5 } & Yes & No & Yes & No \\
\hline Helps in Household Work & $53(48.18)$ & $54(49.09)$ & $65(63.11)$ & $37(35.92)$ \\
\hline Ever hit during arguments & $67(60.91)$ & $40(36.36)$ & $53(51.46)$ & $49(47.57)$ \\
\hline Husbandnot alive & $03(2.73)$ & -- & $01(0.97)$ & - \\
\hline
\end{tabular}


Table 5 depicts that majority $(60.91 \%$ rural and $51.46 \%$ urban women) reported that they had experienced domestic violence.

The data also reveal that the attitude of husbands in urban is better $(63.11 \%)$ to give helping hand in household work as compared to rural area husbands (49.09\%).

Table- 6: Health Status of Respondent

\begin{tabular}{|l|l|l|}
\hline \multicolumn{1}{|c|}{ Health Status } & Rural $(\mathbf{n = 1 1 0})$ & Urban $(\mathbf{n = 1 0 3})$ \\
\hline Osteoarthritis & $02(1.8)$ & $01(0.97)$ \\
\hline Rheumatoid arthritis & - & $01(0.97)$ \\
\hline Cardiovascular disease & $01(0.9)$ & - \\
\hline Diabetes mellitus & $03(2.7)$ & $05(4.85)$ \\
\hline Hypertension & $08(7.27)$ & $13(12.62)$ \\
\hline Fibroid Uterus & $02(1.8)$ & $01(0.97)$ \\
\hline Epilepsy & $02(1.8)$ & - \\
\hline Dysfunctional Uterine Bleeding (DUB) & $01(0.9)$ & - \\
\hline Piles & $01(0.9)$ & - \\
\hline Migraine & - & $02(1.94)$ \\
\hline Renal colic & - & $01(0.97)$ \\
\hline Depression & - & $01(0.97)$ \\
\hline Hypothyroidism & - & $01(0.97)$ \\
\hline Left paraplegia & - & $01(0.97)$ \\
\hline Chronic Cervical pain & - & $01(0.97)$ \\
\hline Cataract & - & $01(0.97)$ \\
\hline Total & $20(18.18)$ & $29(28.15)$ \\
\hline
\end{tabular}

Table 6 depicts that the overall health status of the respondents in rural areas is better as compared to urban areas $(18.2 \%$ and $28.15 \%$ health problems respectively.

Table-7: Comparison of the Empowerment Status of the Respondents

\begin{tabular}{|l|l|l|l|l|}
\hline \multicolumn{1}{|c|}{$\begin{array}{c}\text { Status of } \\
\text { Empowerment }\end{array}$} & \multicolumn{2}{c|}{ Rural (110) } & \multicolumn{2}{c|}{ Urban (103) } \\
\cline { 2 - 6 } & $\begin{array}{l}\text { Employed } \\
(n=08)\end{array}$ & $\begin{array}{l}\text { Unemployed } \\
(n=102)\end{array}$ & $\begin{array}{l}\text { Employed } \\
(n=21)\end{array}$ & $\begin{array}{l}\text { Unemployed } \\
(n=82)\end{array}$ \\
\hline $\begin{array}{l}\text { Participate in } \\
\text { Decision Making }\end{array}$ & $04(50)$ & $22(21.57)$ & $20(95.24)$ & $49(59.77)$ \\
\hline $\begin{array}{l}\text { Have Bank/ Postal } \\
\text { Account }\end{array}$ & $04(50)$ & $30(29.41)$ & $18(85.71)$ & $39(47.56)$ \\
\hline $\begin{array}{l}\text { Have Freedom to } \\
\text { Spend Money }\end{array}$ & $03(37.5)$ & $21(20.59)$ & $19(90.48)$ & $38(52.78)$ \\
\hline
\end{tabular}

Table 7 reveals that status of empowerment in the rural as well as urban women is better among those who are employed.

Table-8: Socioeconomic Status of Respondents Versus Attitude Regarding Different Domestic Issues

\begin{tabular}{|c|c|c|c|c|c|}
\hline Attitude & $\begin{array}{l}\text { SES } \\
\text { Class-I }\end{array}$ & $\left|\begin{array}{c}\text { SES } \\
\text { Class-II }\end{array}\right|$ & $\begin{array}{c}\text { SES } \\
\text { Class-III }\end{array}$ & $\begin{array}{c}\text { SES } \\
\text { Class-IV }\end{array}$ & $\begin{array}{c}\text { SES } \\
\text { Class-V }\end{array}$ \\
\hline \multicolumn{6}{|l|}{ Rural } \\
\hline Desire of Male Child & $00(00)$ & 08 (7.27) & $17(15.45)$ & $\begin{array}{l}47 \\
(42.73)\end{array}$ & $\begin{array}{l}17 \\
(15.45)\end{array}$ \\
\hline $\begin{array}{l}\text { Sex Determination be } \\
\text { Permissible }\end{array}$ & $01(0.9)$ & 05 (4.54) & $09(8.1)$ & $\begin{array}{l}38 \\
(34.54)\end{array}$ & $\begin{array}{l}16 \\
(14.54)\end{array}$ \\
\hline Justify Honour Killings & $00(00)$ & $03(2.7)$ & $20(18.81)$ & $22(20)$ & $07(6.36)$ \\
\hline $\begin{array}{l}\text { Justify Domestic } \\
\text { Violence }\end{array}$ & $00(00)$ & $01(0.9)$ & $03(2.7)$ & $07(6.36)$ & $01(0.9)$ \\
\hline Only Men Should Earn & $00(00)$ & $03(2.7)$ & $13(11.81)$ & $\begin{array}{l}35 \\
(31.82)\end{array}$ & $09(8.1)$ \\
\hline \multicolumn{6}{|l|}{ Urban } \\
\hline Desire of Male Child & $00(00)$ & $\begin{array}{l}22 \\
(21.36)\end{array}$ & $10(9.71)$ & $\begin{array}{l}11 \\
(10.68)\end{array}$ & - \\
\hline $\begin{array}{l}\text { Sex Determination be } \\
\text { Permissible }\end{array}$ & $00(00)$ & $\begin{array}{l}12 \\
(11.61)\end{array}$ & $02(1.94)$ & 07 (6.79) & - \\
\hline Justify Honour Killings & $00(00)$ & $00(00)$ & $00(00)$ & $03(2.9)$ & - \\
\hline $\begin{array}{l}\text { Justify Domestic } \\
\text { Violence }\end{array}$ & $00(00)$ & $00(00)$ & $00(00)$ & $01(0.97)$ & - \\
\hline Only Men Should Earn & $00(00)$ & $00(00)$ & $00(00)$ & $02(1.94)$ & ]$^{-}$ \\
\hline
\end{tabular}

Table 8 depicts that in rural area the attitude regarding domestic issues (Desire of male child, sex determination be permissible, Justify Honour Killings, Justify Domestic Violence and Only Men should earn) is more in SES Class - IV as compared to the attitude of urban women where it is more prevalent in SES Class - II (regarding Desire of Male Child and Permission for Sex Determination) and other issues in urban settings are on the increasing side in SES Class - IV.

\section{Discussion}

The present study was carried out from March 2011 to June 2012 in rural and urban field practice area attached with department of Community Medicine, Government Medical College, Patiala.

After interviewing 110 women in rural and 103 in urban area, the data regarding socio demographic profile of the respondents and their knowledge, attitude and practices regarding various domains of empowerment and their health status was compiled, analyzed statistically. The observations of the study are discussed with the previous studies carried out by different authors.

In this study, total 110 women in rural and 103 women in urban field practice area were interviewed. Majority of the women $(24.54 \%$ rural and $32.04 \%$ urban) were from the age group $28-32$ years. 
Percentage of Sikh population in this study was less (43.64\% rural and $22.33 \%$ urban) as compared to that of Punjab where Sikh population is $53 \%$.

Literacy rate of urban women was $96.12 \%$ which was higher than rural women where literacy rate was $80 \%$. Female literacy rate has increased from $53 \%$ in 2001 to $65.46 \%$ in 2011 in India [6].

Literacy rate in Punjab of women in rural as well as in urban areas is much better than the figures at National Level i.e. NFHS-3 Survey 69\% [7]. According to National Family Welfare Statistics (NFWS) in 2011 it is $71.34 \%$. [8].

In a study conducted in South India in 2007 to assess reproductive health awareness $79.5 \%$ of women aged 13-49 years of age knew that legal age of marriage and reported that child bearing before the age of 20 years is unsafe and endanger life [9].

The mean age of marriage and mean age at first pregnancy was higher in urban area women as compared to the women from rural area. According to NFHS-3 the median age at first marriage in Punjab is 19.8 years among the women.

One-fifth of women age 20-24 years got married before the legal minimum age of 18 years [7] in a study carried out in Kabul by International Centre For Reproductive Health, University of Ghent, Belgium in 2002 the mean age at marriage was 17.2 years .16 .2 percent of the participating women are were married at the age of 14 years or younger, [10].

A study carried out by Aggarwal et al (2004), 84\% pregnant and $92.2 \%$ lactating women were with severe anaemia in 9.2 and 7.3 per cent respectively [13]. thirty eight percent of Punjab women have anaemia, 26 percent with mild, 10 percent moderate and 1 percent with severe anaemia [11].

Status of anaemia according to National Family Welfare Statistics, NFWS (2011) is that $20.8 \%$ in India and $48.05 \%$ in Punjab are anaemic [8].

Amartya Sen analyzed that 100 million women are missing from this planet due to worsening gender ratio in India, China, South and West Asia et. United Nations Children Fund estimated that upto 50 million women and girls are missing from India only because of female foeticide or high mortality rate of girl child due to lack of proper care in home and at health facilities, son preference and sex ratio in India (940) and in Punjab (893) continues to be unfavourable to females.
Discriminating care of a girl child leads to malnutrition and impaired physical, mental and social development of a female child leading to lot of social and health problems in the family and community [10] [14].

The current employment status of women as per survey of NFHS-3 (2005- 06) shows that currently $23 \%$ of married women in Punjab are working or employed [11] [15].

The percentage of all types of violence was higher in the present study carried out in Punjab as compared to women of Punjab reporting domestic violence only $30 \%$ in national family health survey (NFHS 3, 2005-6).[11].

The reason for better health status in rural women may be due to their better life styles, pollution free environment and less psycho social problems as compared to urban areas. So it is evident that if the empowerment of the reproductive women group is enhanced, it will lead to better health status. These attitudes or opinions of the respondents are definitely influenced by the better empowerment status of the women [16].

\section{Conclusion}

From the above information it can be concluded that rural women had a more rigid attitude towards gender issues and urban women on the other hand were more aware of various aspects of empowerment.

The attitudes or opinions of the women in a family are definitely influenced by the better empowerment status of the women. It is also concluded that the reasons for better health status in rural women may be due to their better life style, pollution free environment and less psychosocial problems as compared to the urban area.

It is evident that if the empowerment (education, occupation and financial status) of the reproductive age group women is enhanced it will lead to better health status and modification in the overall health scenario of the family, community, state as well as a country. It will further lead to curb the tendency of honour killings in the society and will create a cordial and peaceful atmosphere.

\section{Contribution by co-Authors}

Dr. Sukhwinder Kaur with the help of Dr. Gurmeet Singh and Dr. Rajinder Singh Balgir 
Contributed to guide, collect and analyse the data. Dr. Yash Mitra along with author and co-authors contributed to construct the tables and helped in corresponding various activities to complete the original article. All the authors read and approved the final manuscript.

\section{What this study adds to the Existing Knowledge}

There are problems of knowledge, attitude and practices regarding existing education system, legal age of marriage, partial family welfare services, MMR, IMR, infanticide and foeticide, Honour killings.

Therefore following steps by the health department in particular and in general the Govt. and community must share the responsibility to empower the women by implementing and enforcing following steps to change the worst scenario existing in rural areas of Punjab and even the slums of urban areas of Punjab:

- Literacy rate is to be enhanced.

- The health and family welfare department should start a campaign in the sub-urban, urban and rural areas to educate the population regarding legal age of marriage, to provide family welfare services in addition to the health services.

- The activities of health and family welfare department will lead to decrease in various morbidity and mortality (MMR, IMR, infanticide, foeticide) rates. It is further recommended that the campaign by the health and family welfare department should be a continuous process to sustain and enhance the health status of the women in the family.

- The community leaders as well as the Government authorities should have a vigorous campaign of education and counseling against honour killings in the community.

- The attitudes or opinions of the women in a family are definitely influenced by the better empowerment status of the women so it is recommended that provision of education, employment and improving their socio economic status by the Government and responsibilities of families will lead to better health status and modification in the overall health scenario of the family, community, state as well as the country.

\section{Reference}

01. Roy TK, Niranjan S. Indicators of women's empowerment in India. Asia-Pacific Population Journal. 2004;Sep;19(3)23-38.

[Crossref]

02. Kirsten Stoebenau and Anju Malhotra. Has Fertility Decline Contributed to Improvements in Women's Lives?. The International Center for Research on Women (ICRW). Nov;2011. [Crossref]

03. World Health Organization (WHO). Health and Development in the 20th Century. GenevaWHO. 1999.

[Crossref]

04. Commission on Status of Women. Review of the implementation of the Beijing declaration and plan for action, the outcomes of the twenty third special session of the General Assembly and its contribution to shaping a gender perspective towards the full realization of millennium Development Goals. United Nations Economic and Social Council (ECOSOC). 2009.

[Crossref]

05. Closing the gap in a generation. Health equity through action on the social determinants of health. WHO, Geneva. 2008.

[Crossref]

06. National Family Health Survey (NFHS-3). Ministry of health and family welfare. 2003.

[Crossref]

07. National Family Welfare statistics (NFWS). Ministry of health and family welfare. 2003, 2011.

[Crossref]

08. National Family Health Survey (NFHS). Ministry of Health and Family Welfare. 2011.

[Crossref]

09. Vinitha, Saudan Singh And AK Rajendran. Level of Reproductive Health Awareness and Factors Affecting It In A Rural Community of South India CT. Health and Population Perspectives and Issues. 2007;30(1)24-44.

[Crossref]

10. Sen Amartya. "More than 100 Million Women Are Missing". The New York Review of Books 37. 20(1990)Web;18 August 2011.

[Crossref] 
11. National Family Health Survey - 3: 20052006;20(1990)Web;18 August 2011.

[Crossref]

12. Dr Kathia V an Egmond. Kap Survey Regarding Reproductive Health Ibnsina HEALTH Program For Afghanistan, Afghansitan ICRH International Centre For Reproductive Health. University Of Ghent, Belgium. Oct;2002.

[Crossref]

13. KN Agarwal, DK Agarwal, A Sharma, K Parsad, et al. Prevalence of anaemia in pregnant \& lactating women in India Healthcare \& Research Association for Adolescents Noida, Nutrition Foundation of India, New Delhi, India. Indian J Med Res. 124,August 2006, pp-173-184. [Crossref]
14. Masood Ali Shaikh, Irshad Ali Shaikh, Anila Kamal, Sobia Masood. Attitudes about honour killing among men and women -perspective from Islamabad. J Ayub Med Coll Abbottabad. 2010;22(3)38-49.

[Article] [Crossref]

15. Nisha Srivastava, Ravi Srivastava. Women Work and Employment Outcome in Rural India. Eco nomic and Political Weekly. 2010;45 (28)49-63. [Crossref]

16. Caren A Grown, Chandrika Bahadur, Jessie Handbury, Diane Elson. "The Financial Requirements of Achieving Gender Equality and Women's Empowerment,". Economics Working Paper Archive wp_467, Levy Economics Institute. 2006.

[Crossref] 